\title{
The Taxonomy, Anatomy and Cytology of Pseudo- bromus africanus (Hack.) Stapf.
}

\author{
By B. de Winter
}

\section{CONTENTS.}

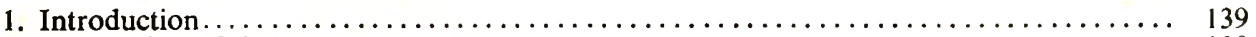

2. Description of the genus $\ldots \ldots \ldots \ldots \ldots \ldots \ldots \ldots \ldots \ldots \ldots \ldots \ldots \ldots \ldots \ldots \ldots \ldots \ldots \ldots \ldots \ldots \ldots \ldots 139$

3. Description of the South African Species. $\ldots \ldots \ldots \ldots \ldots \ldots \ldots \ldots \ldots \ldots \ldots \ldots \ldots \ldots \ldots$

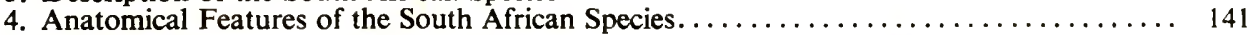

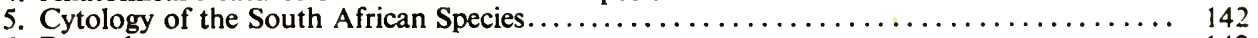

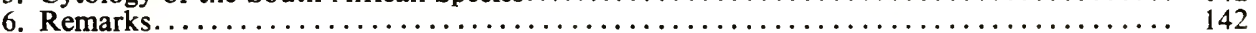

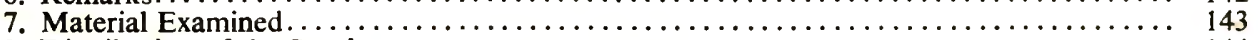

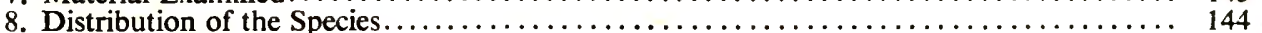

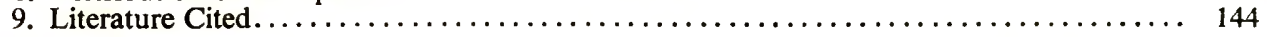

\section{INTRODUCTION.}

Pseudobromus africanus (Hack.) Stapf, the only indigenous species of the genus in South Africa, has until recently remained a most elusive and rare plant. For many years it was known only in herbaria from the type gathering made by Dr. A. Rehmann in the Northern Transvaal, sometime between 1875-1880. Within recent years, however, the species has been recorded from a number of additional localities in the southeastern parts of the Union.

Stapf (5) in 1900 considered the genus a close relative of the genus Festuca L. and consequently a representative of the Festuceae; later (6) he placed the genus near Bromus L. Phillips (7) during 1926 accommodated the genus without comment in the Agrostideae, whereas Camus (1) in 1930 supported Stapf's view both with regard to tribal and generic affinity.

Hence the present investigation was undertaken to throw further light on both its tribal and generic affinities.

In the course of this study a wide series of living and dried material was examined; the living plants were studied both in situ and in cultivation.

The present study is co-ordinated with others on South African Gramineae being undertaken by Dr. H. G. Schweickerdt (University of Pretoria) and Dr. B. S. Fisher (Natal University College).

I wish to express my thanks especially to Dr. H. G. Schweikerdt for his guidance and encouragement in my studies (the present paper comprising part of the thesis presented in partial fulfilment for the degree of Master of Science at the University of Pretoria), to Mr. C. E. Hubbard of Kew for his valuable advice, and furthermore to the Directors and Curators of the various Herbaria who were kind enough to allow me to examine the relevant material.

\section{DESCRIPTION OF THE GENUS. PSEUDOBROMUS K. Schum.}

Pseudobromus K. Schum. in Engler, Pflanzenwelt Ost. Afr., C, p. 108 (1895); Stapf in Dyer, Fl. Cap. VII., 763 (1900); Stent in Bothalia, I, 3, 278 (1924); Bews, World's Grasses, 201 (1929); Camus in Bull. Soc. Bot. France, 77 p. 511 (1930); Phillips, South African Grasses, 174, pl. 55 (1931). 
Spikelets lanceolate, slightly compressed, peduncled, arranged in a panicle; rhachilla disarticulating above the glumes, produced and terminated by a reduced awned lemma. Florets 1 or 2, hermaphrodite, often with a superior (additional) rudimentary floret, the apex of which may project beyond the glumes. Glumes persistent, subequal, lanceolate to oblong, 1-3 nerved. Lemma narrowly lanceolate in profile, sub-herbaceous, rounded on the back, attenuated at the apex into a long straight awn; $3-5$ nerved; margins incurved; callus very short, obtuse, glabrous. Palea subherbaceous, very narrow, two-keeled, entire or nearly so. Lodicules 2 , hyaline, asymmetrical, unequally two-lobed. Stamens 3. Ovary oblong, pubescent at the apex; styles 2, usually fairly short, distinct, ending in slender plumose stigmas; stigmas laterally exserted. Caryopsis oblong, longitudinally channelled on the ventral face; not adhering to the lemma and the palea; hairy at the apex. Plants robust. Leaves flat, usually linear or narrow, herbaceous. Ligule membranous. Panicle large, lax and open, often nodding. Africa.

Species five: three in Madagascar, one in South Africa and one in tropical East

\section{DESCRIPTION OF THE SOUTH AFRICAN SPECIES.}

\section{PSEUDOBROMUS AFRICANUS (Hack.) Stapf. (Fig. 1).}

P. africanus (Hack.) Stapf in Dyer, Fl. Cap. VII, 763 (1900); Stent in Bothalia, 1, 3, 278 (1924); Bews, World's Grasses, Fig. 25, 201 (1929); Phillips, S. Afr. Grasses, 174, pl. 55 (1931).

Synonymy.-Brachyelytrum africanum Hackel in Bull. Herb. Boiss. III, 382 (1896).

Perennial, caespitose, branched from the base, rhizomes short and knotty. Culms few to many, erect or sharply ascending, up to four feet high. slender, simple. Internodes up to eight in number, glabrous, shiny, sometimes weakly striate, pallid to greenish. Nodes constricted, dark green to brown, striate. Sheaths tight, slightly longer than the internodes, open, strongly striate, nerves whitish, scabrous; margins thin, chartaceous. Ligule up to $8 \mathrm{~mm}$. long, membranous, acuminate, glabrous; auricles glabrous; collar inconspicuous, smooth. Leaf-blade dark green, spreading or erect, sometimes more than $40 \mathrm{~cm}$. long and $1.5 \mathrm{~cm}$. wide, tapering into a setaceous point, narrowly lanceolate, flat on both surfaces, thick, more or less rigid, narrowed at the base; nerves on the upper surface scaberulous, less so abaxially; midrib prominent, four or five secondary nerves on each side of the mid-nerve; margins scabrid. Inflorescence a large, fine, lax, terminal, slightly nodding panicle, up to $40 \mathrm{~cm}$. long; rhachis sometimes flattened, smooth below, scaberulous upwards, branches fascicled, terete, flexuous, spreading, fine, up to $20 \mathrm{~cm}$. long, branched. Spikelets 7-9 mm. long, narrowly ovate in outline, awned, dark green, hairy at the base of the glumes, slightly laterally compressed or terete, disarticulating above the glumes. Floret 1, hermaphrodite; rhachilla scabrid, produced to a little more than half the length of the spikelet and bearing a terminal rudimentary lemma; the reduced empty lemma more or less developed, sometimes long-awned and the spikelet thus apparently two-flowered. Glumes up to $6 \mathrm{~mm}$. long, herbaceous membranous, unequal, reaching to about one-half the length of the spikelet; the lower up to $5 \mathrm{~mm}$. long, lanceolate, glabrous, one-nerved, margins hyaline; the upper broadly lanceolate, up to $6 \mathrm{~mm}$. long, finely acuminate, margins hyaline threenerved, lateral nerves evanescent. Body of the lemma about $8 \mathrm{~mm}$. long, a little shorter than the palea, narrowly lanceolate, margins hyaline near the base; midnerve produced into a long capillary awn; awn scabrid, about $20 \mathrm{~mm}$. long. Palea narrowly lanceolate, up to $9 \mathrm{~mm}$. long, herbaceous, strongly two-nerved, two-keeled with a narrow dorsal groove in which the produced rhachilla lies appressed. Callus rounded, hairy, gibbous in lateral view. Lodicules two, oblong, denticulate, swollen at the base, apex hyaline. Stamens three, more or less $6 \mathrm{~mm}$. long, linear, pale yellow in colour. Ovary globose, hairy at the apex; styles two, very short; stigmas plumose. Caryopsis tightly enclosed by the lemma and the palea but not adhering, a little shorter than the palea, about 
$6 \mathrm{~mm}$. long, bearing an apical tuft of hairs, reniform in cross-section; embryo small, about $1 / 6$ the length of the grain; hilum linear stretching the whole length of the grain; epiblast present but small; starch grains compound, ovate- globose, consisting of many polyhedral granules. Reaction of $\mathrm{KI}_{2}$ with starch normal, a deep blue colour.

\section{ANATOMICAL FEATURES OF THE SOUTH AFRICAN SPECIES.}

The Shoot (Fig. 2).

Shoot slender, long, circular in section, covered at the base with imbricate brown scales. Leaves arranged on a very short stem, young leaves protected by the sheaths of the outer leaves.

The anatomy of the stem conforms to the usual type. The stem is distinctly hollow. Two or three rows of vascular bundles lie near the periphery of the stem. The pith cavity is lined by thin-walled parenchymatous cells.

The root is typical of the monocotyledonous type. The endodermis cells are very strongly lignified, especially the inner tangential walls. Outer tangential walls only slightly thickened. The thickened walls show distinct striations and pits. An interesting point is that the pericycle cells are in some places thickened, and closely resemble endodermis cells.

The Leaf-blade (Fig. 4).

Leaf Anatomy.

Hand cut sections made from the upper part of the lower third of a full-grown leaf were studied. Surface sections were used to study the epidermis. The study of macerated material of the blade proved useful in elucidating certain doubtful points. The drawings were made either with a Leitz Panphot or an Abbé drawing apparatus.

Abbreviations used in the text-figures are as follows:

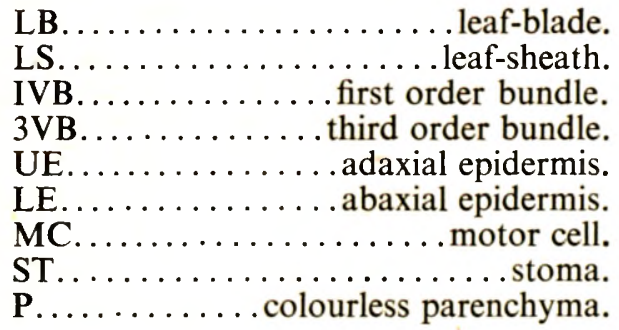

C.................. chlorenchyma. BS............. inner bundle sheath. S.......mechanical tissue or stereome. EC........ long tapering epidermal cell. OC........... one-celled curved hairs. RS. .constricted part of chlorenchyma ceil.

IS.............. intercellular spaces.

Leaf-blade tapering towards the margins, near the midrib about $0.39 \mathrm{~mm}$. thick, near the margins about $0.18 \mathrm{~mm}$. thick. Abaxial surface more or less flat; the adaxial finely grooved (vascular bundles slightly projecting). Keel prominent, rounded, with sides sloping. Epidermis (Figs. 3 and 4): Motor cells 3-5, poorly differentiated near the margins, otherwise large occupying $1 / 3-\frac{1}{4}$ the leaf thickness. No silicified cells present, cells very similar, long and narrow, tapering towards the ends. Stomata occurring on both surfaces; abaxially in 1-2 rows between the bundles, absent between some of the third order bundles; adaxially (Fig. 4) in 3-4 rows on both sides of the first and second order bundles and in 2-3.rows on both sides of the third order bundles. A single row of short one-celled curved hairs occur adjacent to the bundles ab- and adaxially. Longer one-celled straight epidermal hairs are found in the region of the stomata. Vascular bundles irregularly distributed. First order bundles 6-10 excluding the midvein; inner bundle sheath present and consisting of 16-22 lignified cells; outer bundle sheath consisting of a smaller number of fairly large thin-walled parenchymatous cells which contain some chloroplasts. Second order bundles up to 12 in number; inner bundle sheath consisting of 12-14 lignified cells; outer sheath of thin-walled parenchymatous cells. Third order bundles 14-17 in number; inner sheath consisting of about 10 
lignified cells; outer of smaller number of parenchymatous cells. Midrib large, composed of a large first order bundle with adaxial and abaxial stereome strands, furthermore two second order bundles with their stereome strands; colourless, isodiametric parenchyma cells present as well as a few chlorenchyma cells. Margin tapering to a fairly narrow edge covered with small curved hairs. Chlorenchyma cells large, regular to irregular in places. Smaller round cells present between the chlorenchyma. The chlorenchyma cells in longitudinal view possess deeply undulating walls (Fig. 5C). If the section passes through the constricted part of a cell a small round cell is seen in the transverse section. Stereome weakly developed; present in the keel and above the mid-vein as well as abaxial to all bundles, but adaxial to first order bundles and usually all the third order bundles.

\section{CYTOLOGY OF THE SOUTH AFRICAN SPECIES.}

\section{Origin of the Material.}

The plants studied were gathered at Magoebaskloof, De Hoek. The type locality is given as Magoebaskloof Houtbosch.

Technique.

Only root tips were used. These were collected at about $10.30 \mathrm{a} . \mathrm{m}$. and fixed in La Cours 2 B.P. fixative for 24 hours, dehydrated with xylol and embedded in wax with a melting point of $54^{\circ} \mathrm{C}$. Sections were cut at 10-12 $\mu$ and stained by the iodinegentian violet technique described by La Cour (9).

The chromosome number was determined by making camera lucida drawings of several equatorial plates. Use was made of a stage micrometer to indicate the scale of the drawing.

\section{Observations.}

Pseudobromus africanus, $2 \mathrm{n}=28$ (Fig. 6).

Basic number (probably) $=7$.

The chromosomes are of the relatively big festucoid type. The chromosome number corresponds with that of Festuca and Bromus, where many species with $2 \mathrm{n}=28$ occur.

The length of the chromosomes vary from more or less $4 \mu$ to more or less $10 \mu$. In the metaphase plates studied the bigger chromosomes lie on the periphery of the spindle, while the shorter ones occupy a more central position (Fig. 6).

\section{REMARKS.}

The genus Pseudobromus was created by K. Schumann (4) during 1895 on a plant which he described as Pseudobromus silvaticus.

On the basis of the one-flowered spikelet Schumann considered the genus to be related to Deyeuxia Beauv. of the Agrostideae, simultaneously pointing out certain differences. He furthermore mentions the superficial resemblance in facies of $P$. silvaticus and Bromus asper Murray, thereby indicating the source of the generic name Pseudobromus.

In the same year Hackel (3) described a species Brachyelytrum africanum which, however, differed from the genus, sensu stricto, in possessing spikelets with relatively large glumes and a lemma with a rounded, not oblique, callus. During 1900 Stapf (5) for sound reasons, transferred Hackel's species to the genus Pseudobromus, thus effecting the combination $P$. africanus (Hack.) Stapf.

Stapf (5) in 1900 evidently did not agree with Schumann concerning the generic relationship of Pseudobromus, since he states that the latter was closely allied to that of Festuca L. At a later date, however, he (6) places the genus Pseudobromus next to the 
genus Bromus in his key to the genera of tropical African grasses. It must be assumed, however, that the position occupied by the genus Pseudobromus in the key referred to is one of convenience rather than one of natural affinity.

Phillips (7) places the genus under the Agrostideae without comment, in all probability merely following the arrangement of genera in De Dalle Torre and Harm's " Genera Siphonogamarum."

A. Camus (1), in her monographic account of the genus, supports Stapf's view (6) and furnishes a number of differential characters by which the genera Bromus and Pseudobromus may be readily distinguished. Her account includes the study of both African and Madagassian material comprising five species, resulting in an augmented and amplified conception of the genus, particularly with regard to the number of fertile florets per spikelet and the nature of the caryopsis.

Despite the above valuable contributions the difficulty still remains, viz., the close resemblance in facies and structure of members of Pseudobromus K. Schum. with certain species of Festuca L. The only tangible characters by which these genera may be distinguished in the case of Pseudobromus, appear to be the one- to two-flowered nature of the spikelet with an additional rudimentary lemma inserted on the produced rhachilla and the fewer nerved lemmas. This genus represents an extremely advanced type, which by the reduction of the upper florets could possibly have originated from a more primitive type, e.g., Festuca L.

Although the genus Pseudobromus resembles in facies certain species of Bromus, a number of fundamental differences are exhibited by these two genera, viz., Bromus possesses laterally compressed spikelets, which are several- to many-flowered; the keels of the palea are rigidly ciliate or ciliolate; the ovary is produced into a terminal appendage on which the styles are laterally inserted; the caryopsis usually adheres to the lemma and the palea; an epiblast is lacking in the embryo (2) and the starch grains are simple. All these characters are, however, not met with in the genus Pseudobromus, and for these reasons it is evident that the nearest ally of the genus in question appears to be that of Festuca L.

The anatomical study of the root, stem and leaf did not reveal striking characteristics. The endodermis of the root here and there appears to be two-layered, probably due to the pericycle cells with walls thickened in a way similar to those of the endodermis cells.

The chlorenchyma cells of the leaf in macerated condition reveal the presence of strongly undulating walls suggestive of rather conspicuous intercellular spaces; the latter are usually overlooked in transverse sections of the leaf.

\section{MATERIAL EXAMINED.}

All material cited was actually seen. The following abbreviations indicate the herbaria where the specimens are deposited:-

\begin{tabular}{|c|c|}
\hline \multirow{2}{*}{\multicolumn{2}{|c|}{ Bolus Herbarium, Cape Town. }} \\
\hline & \\
\hline CTM. & South African Museum, Cape Town. \\
\hline GRA. & Albany Museum, Grahamstown. \\
\hline NH. & Natal Herbarium, Durban. \\
\hline NU. & Natal University College, Pietermaritzburg. \\
\hline PRE. & National Herbarium, Pretoria. \\
\hline STELI & University of Stellenbosch. \\
\hline U & $\mathrm{U}$ \\
\hline
\end{tabular}

Cape Province.-Tembuland Forests, V. 1919, R. Baur 491 (BOL, CTM). East Griqualand, Imsikini near Hoha, III., 1928, van Tonder 5 (PRE).

Natal Province.-New Hanover district: Blinkwaterbos, kom in diep skadu voor, II., 1944, Schweickerdt 1534 (STELL, UPR). Lions River district: Karkloof Forest, 
alt. 5,000', III., 1940, Ryecroft 45 (NH, PRE). Do., Karkloof Forest, common, V., 1940, B. S. Fisher 138 (NH). Do., Karkloof Forest, II., 1940, Ryecroft 3 (NH, NU). Zululand, N'kandla district: Il., 1940, frequent in forest, alt. 5,000', Qudeni, Fisher et Schweickerdt 115, (NH, NU, PRE). Do., Qudeni, in shade in forest, alt. 5,000', II., 1940, Fisher et Schweickerdt 83 (NH, NU). Do., Qudeni, frequent in forests, alt. $5,000^{\prime}$, II., 1940, Fisher et Schweickerdt 16 (NH, NU). N'Kalhlondla Forest, Cathed ral Park Area, alt. 5,000', II., 1943, Schelpe 203 (NU).

Transvaal Province.-Pietersburg district: Haenertsburg, Houtbos, De Hoek, meerjarig, volop in bosse, Schweickerdt 1568 (UPR). Do., Haenertsburg, Houtbos, De Hoek, in die bosse, I., 1945, Schweickerdt 1563 (UPR). Letaba district: Houtbosch, 1875-1880, Rehmann 5732 (GRA) (type number); Do., Magoebaskloof, kiam oop plekke in bos, IV., 1946, de Winter 104 (UPR). Do., Houtbosch, III., 1946, Schweickerdt 1601 (UPR). Do., Maripskop, IV., 1946, boonste bosse, nie volop nie, Schweickerdt 1616 (UPR). De Winter 129 and 271 (cultivated at University of Pretoria, cytologically investigated, PRE, UPR.)

TyPE SPECIMEN (not examined).-Rehmann 5732, Houtbosch Letaba district, in Herb. Mus. Bot. Zurich.

\section{DISTRIBUTION OF THE SOUTH AFRICAN SPECIES.}

The distribution of this species is limited to the higher parts of the mistbelt forests which occur along the south-eastern and eastern escarpment. According to data obtained from herbarium sheets it does not occur below an altitude of about 4,000' above sea level (Fig. 7).

The distribution of the genus is apparently also limited to high altitudes of Africa and Madagascar. No gatherings have been reported under 4,000' for any of the species. $P$. silvaticus K. Schum. apparently reaches the high altitude of $8,000^{\prime}$ in the East African tropics.

\section{LITERATURE CITED.}

1. Camus, A......... In Bull. Soc. Bot. France 77, 512 (1930).

2. Kennedy, P. B..... The structure of the Caryopsis of Grasses with reference to their Mophology and Classification in Bull. 19, U.S. Dept. of Agric. (1889).

3. Hackel, E........ In Bull. Herb. Boiss., 3, 382 (1895).

4. SchumanN, K....... In Engler's Pflanzenwelt Ost. Afr. C., 180 (1895).

5. Stapf............ In Dyer, Fl. Cap. VII, 763 (1900).

6. Stapf.......... In Prain, Fl. Trop. Afr., IX, I, 24 (1917).

7. Phillips, E. P...... Gen. S. Afr. Flow. Plants (1926). 


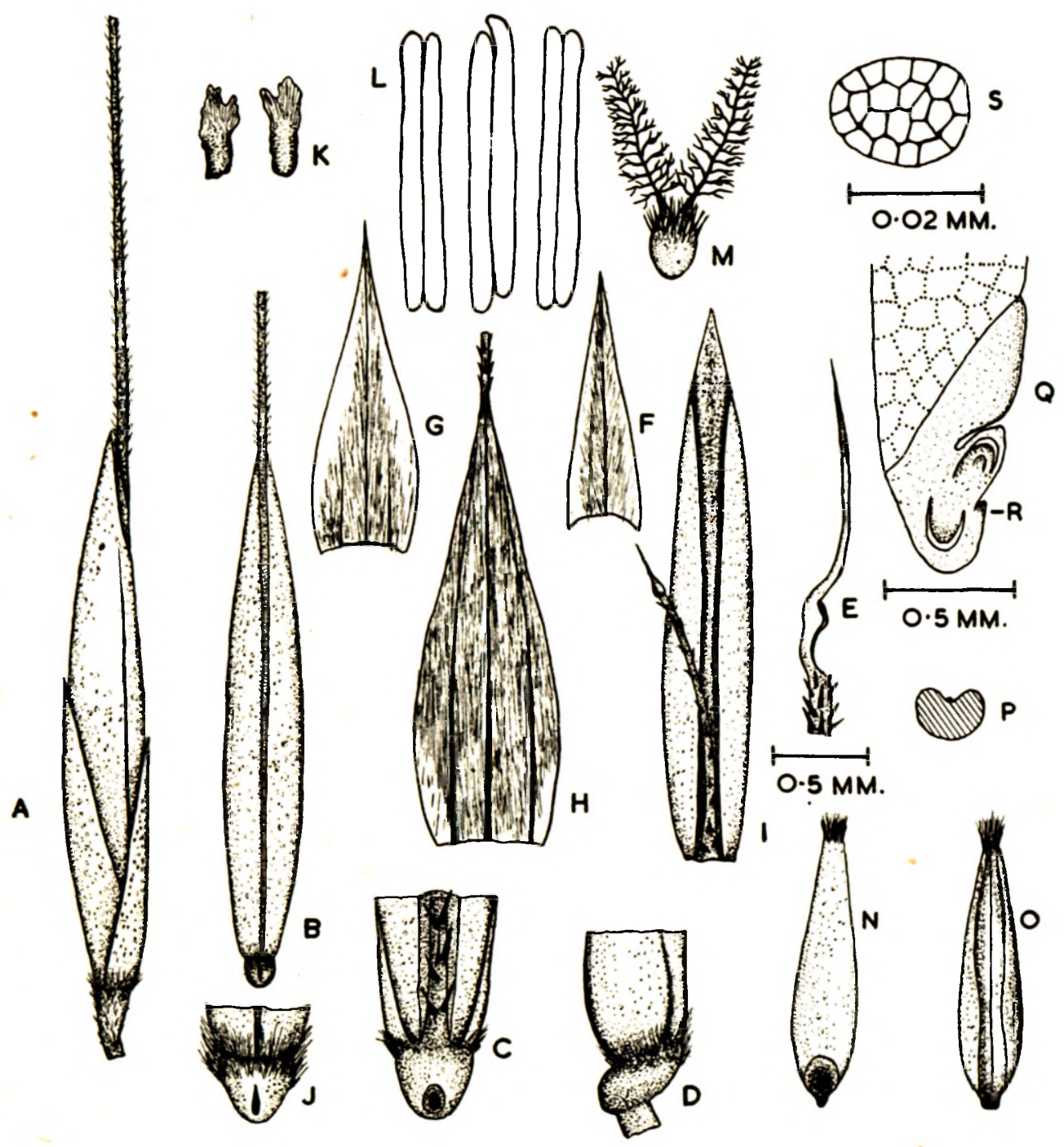

Fig. 1. $A-$-Spikelet. $B-$ Fertile floret, dorsal view. $\quad C$-Base of floret, showing produced rhachilla and rounded callus. $D$-Side-view of the floret, showing the gibbous base and short rhachilla. E-Sterile reduced lemma inserted at the top of the produced rhachilla. $F$-Lower glume. $G$-Upper glume. $H$-Lemma, dorsal view. $I$-Palea with produced rhachilla. $J$-Callus. $K$-Lodicules. $L$-Anthers. $M$ Pistil. $N$-Caryopsis, dorsal view. $O$-Caryopsis, ventral view. $P$-Cross-section of the caryopsis. $Q$-Longitudinal section of the embryo. $R$-Epiblast. $S$-Compound starch grain.-(Schweickerdt 1534.) 


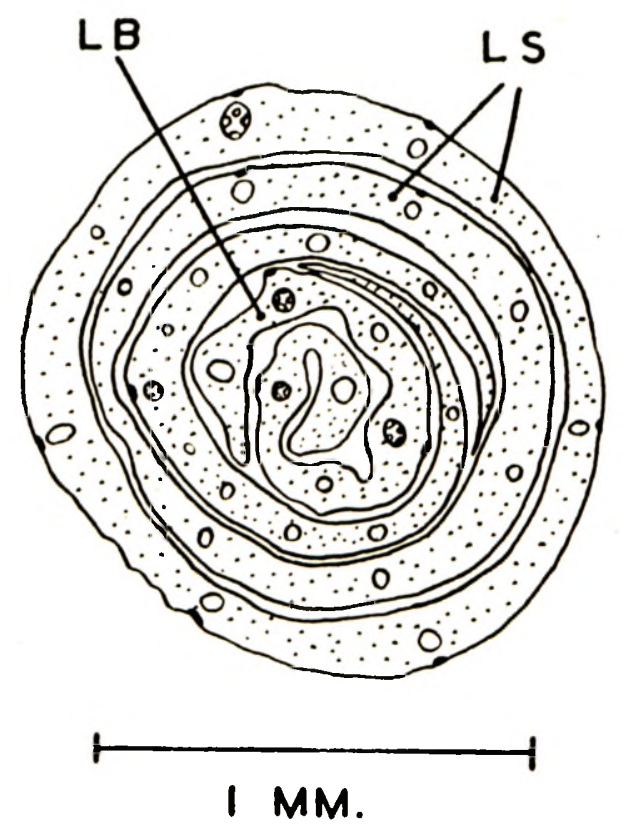

FIG. 2.-Cross-section of the shoot.-(Schweickerdt 1534.) 


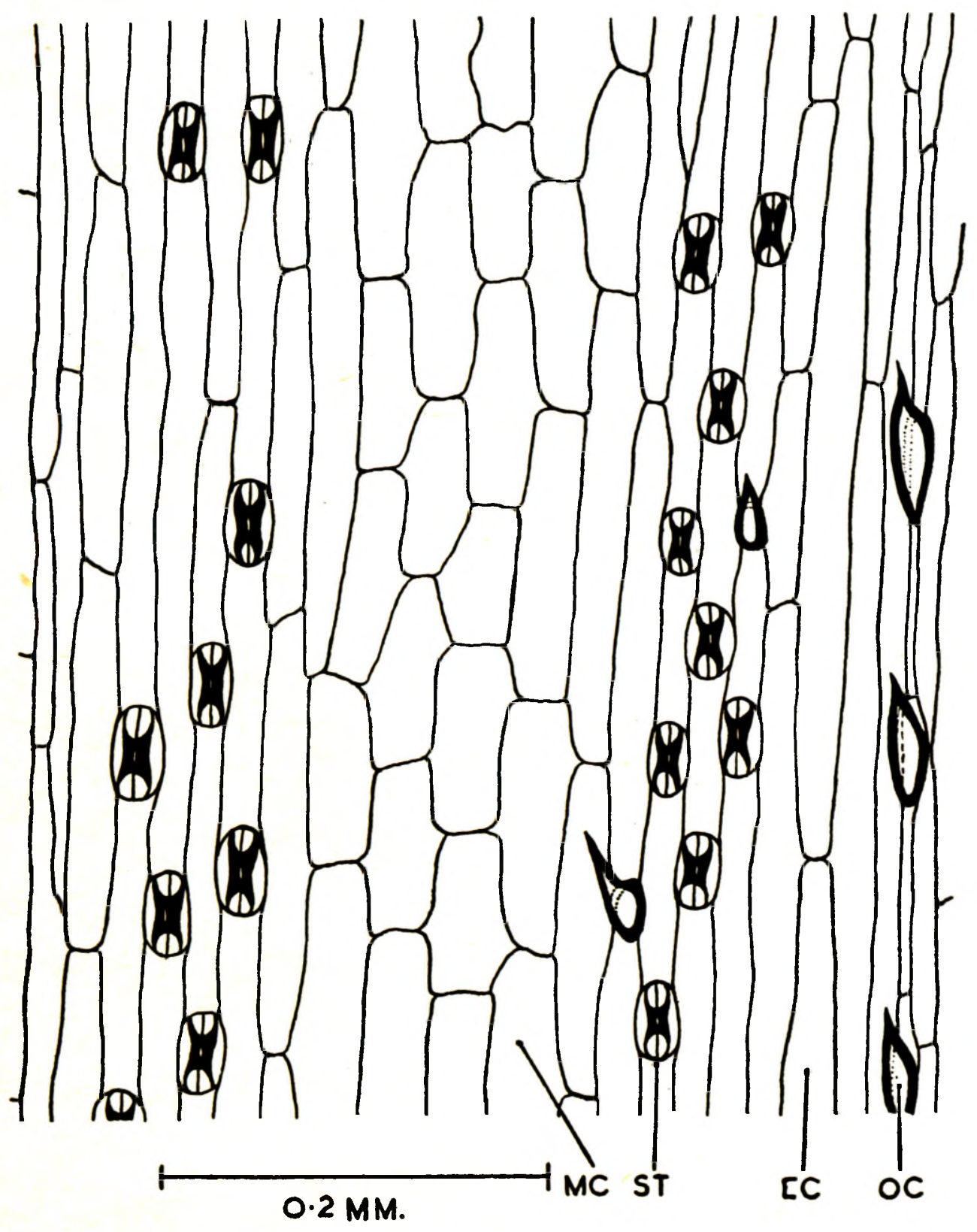

FIG. 3.-Abaxial epidermis.-(Schweickerdt 1534.) 


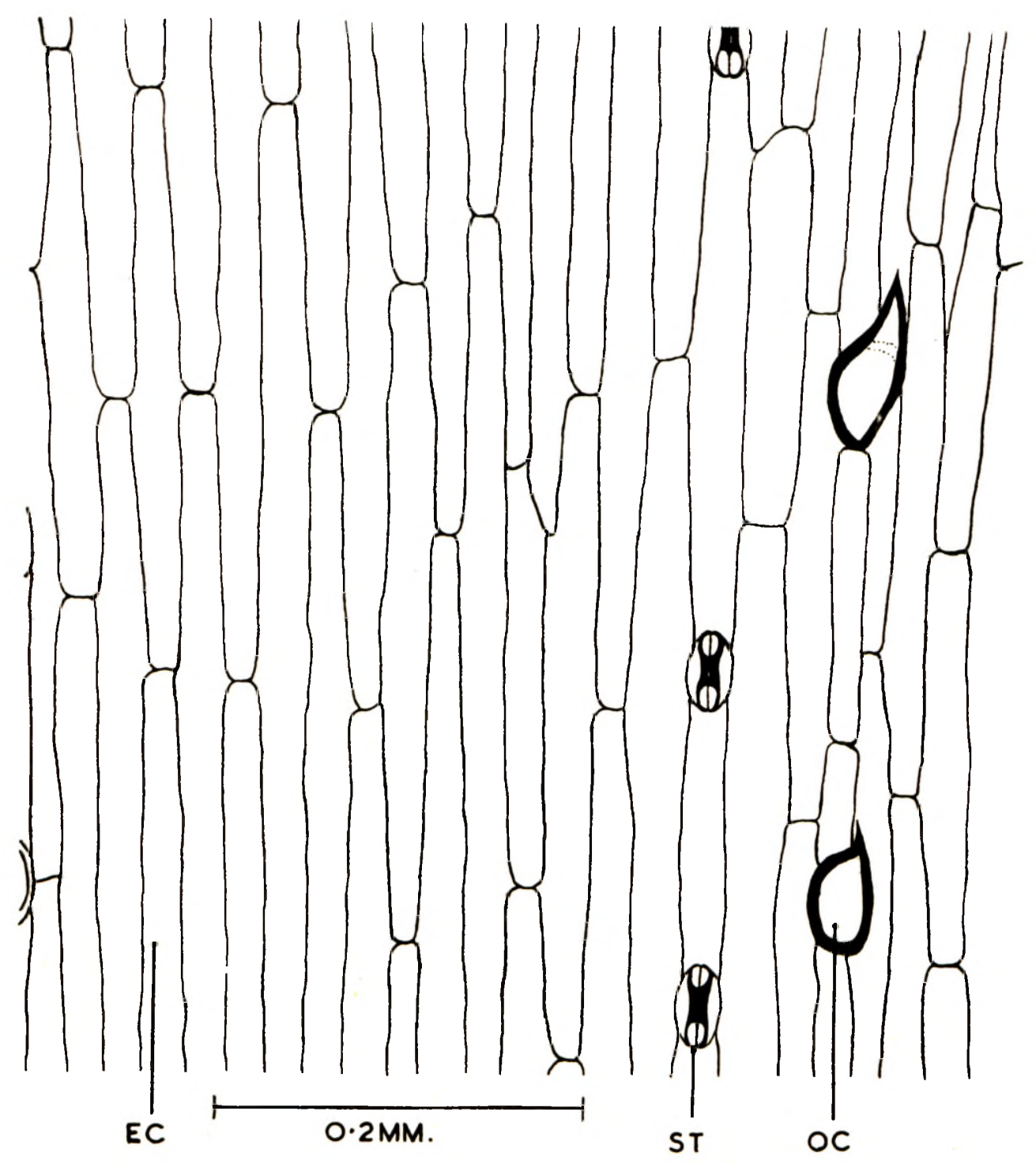

FIG. 4.-Adaxial epidermis.-(Schweickerdt 1534.) 


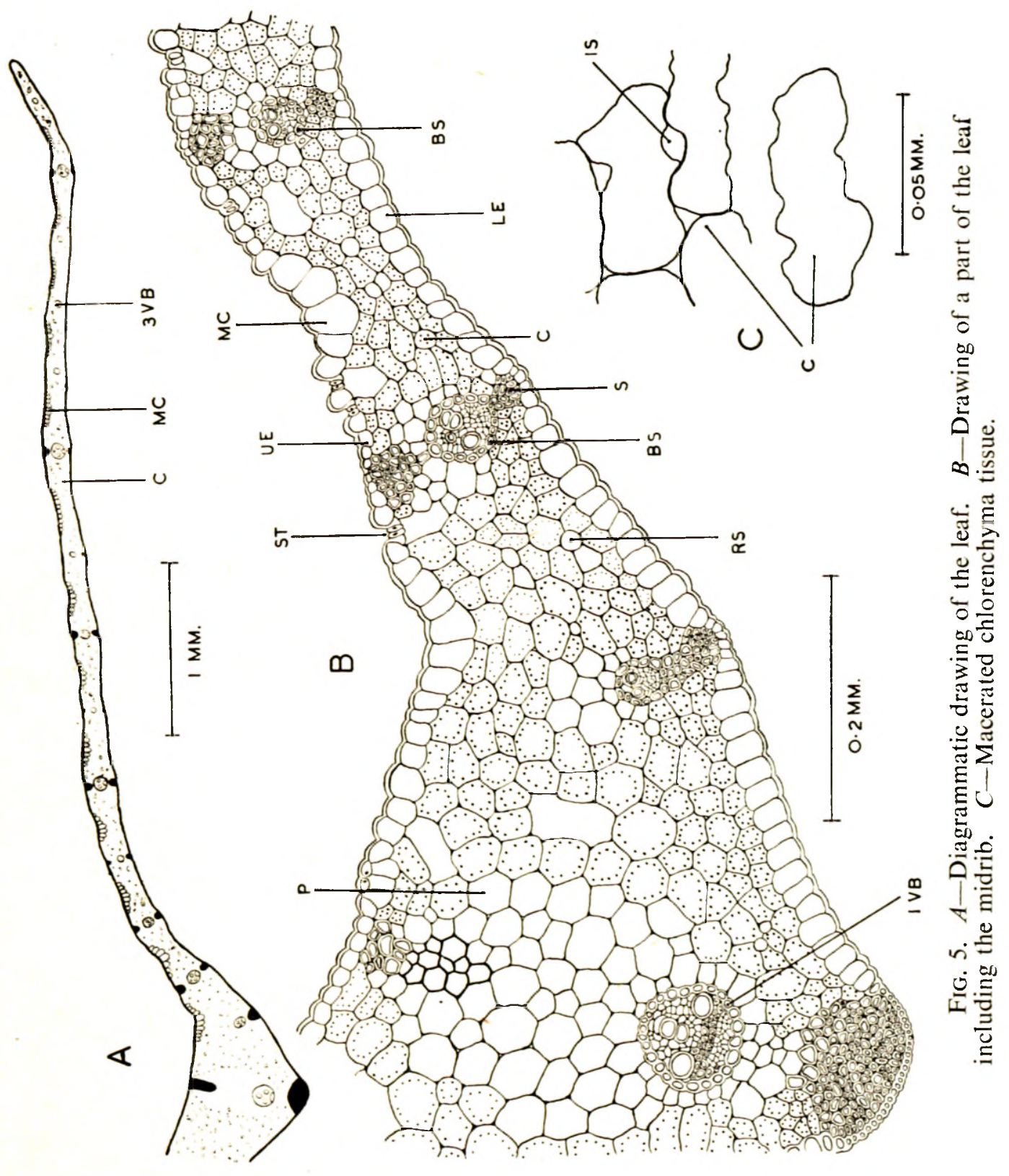




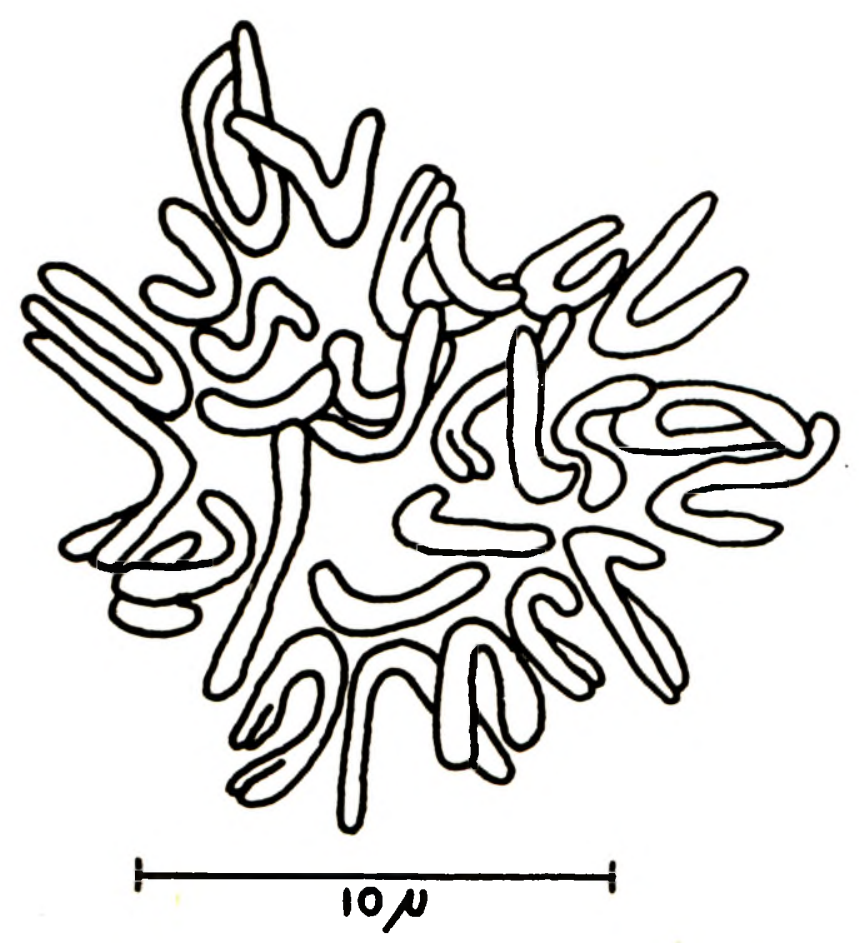

FIG. 6.-Polar view of a metaphase of a root tip cell.-(de Winter 129 and 271.) 


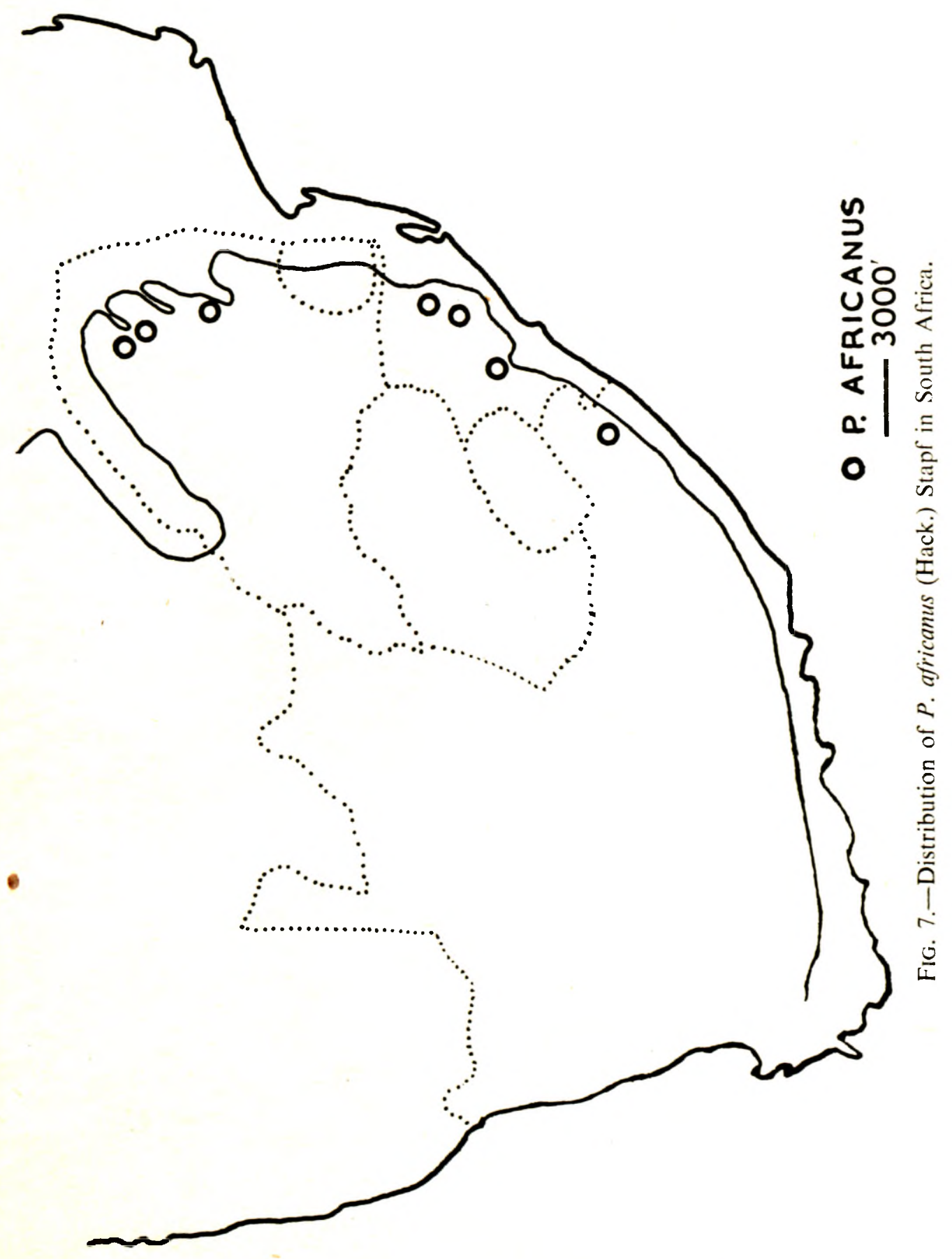


